\title{
Notes
}

\section{Confidentiality of Pretrial Services Information under the Speedy Trial Act*}

In 1974 Congress passed the Speedy Trial Act to "assist in reducing crime and the danger of recidivism by requiring speedy trials and by strengthening the supervision over persons released pending trial."1 Title $\mathrm{II}^{2}$ of the Act establishes experimental pretrial services agencies (PSAs) in 10 federal districts. Five of these agencies are governed by the Division of Probation of the Administrative Office of the United States Courts, and five are controlled by boards of trustees. ${ }^{3}$ The purpose of Title II is to test whether PSAs can reduce pretrial deten-

- Much of the information in this Note is the product of personal interviews. Special thanks are given to Judd Kutcher, Elsie Reid, and Guy Willetts of the Administrative Office of the United States Courts; Dan Ryan, Chief Pretrial Services Officer in the Eastern District of New York; and Bruce Beaudin, Director of the District of Columbia Bail Agency.

1. Pub. L. No. 93-619, preamble, 88 Stat. 2076 (1974). Congress believed that speedy trials would reduce crime primarily by shortening the period during which defendants released pretrial could commit crimes. Lengthy pretrial delays also result in loss of evidence and disappearance of witnesses, forcing the Government to abandon otherwise valid prosecutions. S. REP. No. 93-1021, 93d Cong., 2d Sess. 6-8 (1974) [hereinafter cited as SENATE REPORT].

2. 18 U.S.C. $\$ \$ 3152-3156$ (Supp. V 1975).

3. Id. $\S 3153(\mathrm{a})$, (b). See H.R. REP. No. 93-1508, 93d Cong., 2d Sess. 46-47 (1974), reprinted in [1974] U.S. Code Conc. \& Ad. News 7420-21. The Division of Probation operates PSAs in the Central District of California, the Northern District of Georgia, the Northern District of Illinois, the Southern District of New York, and the Northern District of Texas. The remaining PSAs are administered by boards of trustecs composed of the chicf judge of the federal district court, the United States attorney, the public defender, a member of the local defense bar, the chief probation officer, and representatives of community organizations appointed by the chief judge. 18 U.S.C. $\$ 3153(\mathrm{~b})(2)$ (Supp. V 1975). Boards of trustees operate PSAs in the District of Maryland, the Eastern District of Michigan, the Western District of Missouri, the Eastern District of New York, and the Eastern District of Pennsylvania [hereinafter referred to as trustee districts]. Administrative Office of the United States Courts, Report on the IMPLEMentation of Title I and Title II of the Speedy Trial Act of 1974, at 26 (1976) [hereinafter cited as Administrative Office Report]. The statute requires the Director of the Administrative Office of the United States Courts to report to Congress, comparing the accomplishments of those districts governed by the Division of Probation with those governed by boards of trustees. 18 U.S.C. $\$ 3155$ (a) (Supp. V 1975).

Technical assistance is provided to all 10 districts by the Pretrial Services Branch of the Division of Probation of the Administrative Office of the United States Courts. AdMinistrative OfFice Report, supra at 28. 
tion, absconding, and the incidence of crimes committed while on bail. 4

Congress believed that these objectives could be achieved in part through better-informed release decisions, more careful selection of pretrial release options for defendants, and supervision of some released defendants. ${ }^{5}$ Accordingly, Title II authorizes PSAs to collect information relevant to the pretrial release decision, to recommend appropriate release conditions, and to supervise persons on release."

PSAs must depend primarily upon defendants for the information necessary to carry out these functions. Congress was concerned that the use of this information for purposes other than bail determination might discourage defendants from providing complete and accurate information. ${ }^{7}$ Therefore, in order to encourage defendants to cooperate with the PSA program, Title II places certain restrictions on the use of information gathered by PSAs. ${ }^{8}$ Further restrictions have

4. Senate Report, supra note 1, at 24-25. See 18 U.S.C. \$ 3155 (a) (Supp. V 1975).

By introducing crime control objectives into the pretrial release process, Title II seems to contemplate that PSAs will consider the likelihood that a defendant may commit a crime if released. Under the Bail Reform Act, 18 U.S.C. $\$ \$ 3041,3141-3143,3146-3152$, 3568 (1970) (governing release of federal defendants), however, conditions of pretrial release may be imposed in noncapital cases only to ensure a defendant's appearance at trial. 18 U.S.C. $\$ 3146$ (a) (1970); United States v. Leathers, 412 F.2d 169, 171 (D.C. Cir. 1969). See also Stack v. Boyle, 342 U.S. 1, 4-5 (1951). Since Title II does not explicitly change existing law, there is a serious tension between the crime control goals of Title II and the legitimate purposes of bail that is not acknowledged in the statute or its legislative history.

Congress recognized, however, that, despite legal restrictions, judges routinely consider the safety of the community in making relcase decisions and may detain defendants because of fear that if released they will commit subsequent crimes. SENATE RIPORT, supra note 1 , at 24-25. Without amending the Bail Reform Act or endorsing preventive detention, Title II attempts to facilitate pretrial release by accommodating these concerns through the provision of PSA supervision as an alternative to detention.

5. SENATE REPORT, supra note 1 , at 24-25.

6. 18 U.S.C. $\$ 3154$ (Supp. V 1975). PSAs were modeled after the District of Columbia Bail Agency, which was created by Congress to assist the D.C. courts in implementing the Bail Reform Act of 1966, id. $\$ \$ 3041,3141-3143,3146-3152,3568$ (1970). ScNATE RcPorT, supra note 1 , at 25,51 . The Bail Reform Act revised existing bail practices in federal courts by creating a presumption in favor of release without money bond before trial. This reform was based on the experience of a number of voluntary bail projects, which had demonstrated that family ties, employment, residence in the community, and the absence of a substantial criminal record are factors more likely to cnsurc the appearance of a defendant than the posting of bond. S. REr. No. 750, 89th Cong., Ist Sess. 1 (1965). The D.C. Bail Agency was established to provide information regarding these factors; its functions were later expanded to include supervision of released defendants.

7. SENATE REPORT, supra note 1 , at 52.

8. 18 U.S.C. $\$ 3154(1)$ (Supp. V 1975) provides in part:

[S]uch information as may be contained in the agency's files or presented in its report or which shall be divulged during the course of any hearing shall be used only for the purpose of a bail determination and shall otherwise be confidential. In their respective districts, the Division of Probation or the Board of Trustees shall issue regulations establishing policy on the release of agency files. Such regulations shall create an exception to the confidentiality requirement so that such information 
been imposed through regulations issued by the Division of Probation and the boards of trustees. ${ }^{9}$

Title II requires the Director of the Administrative Office of the United States Courts to report annually to Congress on the progress of the PSA experiment. ${ }^{10}$ The first annual report, submitted on September 30, 1976, notes that "one serious problem already facing pretrial services agencies is that of 'confidentiality." "11 The report concludes that the problem must be studied and that present regulations should be revised on the basis of further PSA experience. ${ }^{12}$

This Note argues that current confidentiality restrictions conflict with the stated objectives of Title II. The Note examines the reasons for confidentiality in light of the structure and purposes of the Title II program, and offers a framework for striking a balance between

shall be available to members of the agency's staff and to qualified persons for purposes of research related to the administration of criminal justice. Such regulations may create an exception to the confidentiality requirement so that access to agency files will be permitted by agencies under contract [to act as custodians of persons released]; to probation officers for the purpose of compiling a presentence report and in certain limited cases to law enforcement agencies for law enforcement purposes. In no case shall such information be admissible on the issue of guilt in any judicial proceeding, and in their respective districts, the Division of Probation or the Board of Trustees may permit such information to be used on the issue of guilt for a crime committed in the course of obtaining pretrial release.

9. Title II requires the Division of Probation and the boards of trustees in the five trustee districts to "issue regulations establishing policy on the release of agency files." Id. $\$ 3154(1)$. In 1976 the Division of Probation promulgated such regulations. Division of Probation Regulations-Confidentiality of Pretrial Services Agency Information (undated) (on file with Yale Law Journal) [hereinafter cited as Division of Probation Regulations]. The General Counsel of the Administrative Office of the United States Courts has issued a legal memorandum in support of these regulations. Confidentiality of Pretrial Services Agencies Information (undated) (on file with Yale Law Journal) [hereinafter cited as Legal Memorandum].

PSAs in the District of Maryland, the Western District of Missouri, and the Eastern District of New York have developed written confidentiality regulations. Rules for Confidentiality of PRETRIAL SERVICES, District of Maryland (undated) (on file with Yale Law Journal) [hereinafter cited as Maryland Regulations]; Proposed Rules and Regulations Pertaining to the Confidentiality and Release of Information of the Pretrial Services Agency, Western District of Missouri (undated) (on file with Yale Law Journal) [hereinafter cited as Proposed Missouri Regulations]; Statement of General Policy as to Functions and Procedures of the Pretrial Services Agency for the United States District Court, Eastern District of New York $\$ 2$ (undated) (on file with Yale Law Journal) [hereinafter cited as Eastern New York Regulations].

PSAs in the Eastern District of Michigan and the Eastern District of Pennsylvania simply follow the Division of Probation regulations. Telephone Interview with Arthur Goussy, Chief Pretrial Services Officer, Eastern District of Michigan (Oct. 19, 1976) (notes on file with Yale Law Journal) [hereinafter cited as Goussy Interview]; Telephone Interview with Robert Williams, Chief Pretrial Services Officer, Eastern District of Pennsylvania (Oct. 19, 1976) (notes on file with Yale Law Journal) [hereinafter cited as Williams Interview].

10. 18 U.S.C. $\$ 3155$ (a) (Supp. V 1975).

11. ADMinistrative OfFice RepoRT, supra note 3 , at 42.

12. Id. at $42-43$. 
confidentiality and disclosure that is consistent with the role of the PSA in the pretrial release process. A screening procedure for the disclosure of PSA information that would help maintain this balance is proposed. Finally, the Note evaluates specific instances in which current restrictions imposed by the statute and regulations conflict with the goals of Title II and thus jeopardize the effective administration of the pretrial release process and the success of the PSA program.

\section{PSA Procedures}

\section{A. Collection of Information}

Title II authorizes PSAs to "[c]ollect, verify, and report promptly to the judicial officer information pertaining to the pretrial release of each person charged with an offense,"13 to "recommend appropriate release conditions for each such person," 14 and to "[s]upervise persons released into [their] custody."15

In order to gauge the likelihood that a defendant will appear for subsequent court proceedings, the PSA interviews each defendant to elicit information about his community ties, financial resources, employment, family situation, and criminal record. ${ }^{10}$ The defendant is not asked any questions regarding the circumstances of the offense

13. 18 U.S.C. $\$ 3154(1)$ (Supp. V 1975).

A judicial officer is "any person or court authorized pursuant to section 3041 of this title [Title 18, U.S.C.], or the Federal Rules of Criminal Procedure, to bail or otherwise release a person before trial or sentencing or pending appeal in a court of the United States, and any judge of the Superior Court of the District of Columbia." Id. $\$ 3156(\mathrm{a})(1)$. Among those so authorized by $\$ 3041$ are United States Justices, judges, or magistrates. The initial bail hearing is ordinarily conducted by a United States magistrate. FED. $\mathbf{R}$. Crim. P. 5. Subsequent proceedings are ordinarily conducted by a magistrate or the district court judge to whom the case has been assigned for trial.

14. 18 U.S.C. $\$ 3154(1)$ (Supp. V 1975).

15. Id. $\S 3154(3)$. PSAs may also operate facilities for the custody or care of released defendants such as residential halfway houses or addict and alcoholic treatment centers, id. $\S 3154(4)$, and assist released defendants in obtaining employment and medical, legal, or social services, $i d$. $\$ 3154(7)$. They also prepare biweckly pretrial detention reports, required under Rule $48(\mathrm{~g})$ of the Federal Rules of Criminal Procedure, which are designed to aid the district court in eliminating unnecessary detention, id. $\$ 3154(8)$.

16. The factors that the court may consider in setting release conditions in noncapital cases include:

the nature and circumstances of the offense charged, the weight of the evidence against the accused, the accused's family ties, employment, financial resources, character and mental condition, the length of his residence in the community, his record of convictions, and his record of appearance at court proceedings or of flight to avoid prosecution or failure to appear at court proceedings.

Id. $\S 3146(\mathrm{~b})(1970)$. In capital cases the court may also consider the risk of danger to another person or to the community. $I d$. $\$ 3148$. 
for which he has been arrested. ${ }^{17}$ To verify the information provided by a defendant, the PSA contacts his family, friends, or employer, and checks his criminal record with federal and local law enforcement agencies. ${ }^{18}$

Based on the information collected, the PSA submits a brief report to the judicial officer summarizing the information gathered and recommending release conditions for each defendant. ${ }^{10}$ This report

17. Title II does not prohibit the collection of information regarding the offense. Although such information is relevant to the bail determination under id. $\$ 3146(\mathrm{~b})$, Division of Probation Regulation 1(a)(2) provides:

A pretrial services officer shall record only information pertinent to the determina-

tion of bail and shall not record, or indicate in any form, any information related to

an alleged offense(s), except such information as is obtained from documents of

public record. When such information of public record is obtained and recorded,

the pretrial services officer shall identify its source.

All five trustee districts have similar regulations. Maryland Regulation 1(a)(2), supra note 9; Proposed Missouri Regulation 1(a)(2), supra note 9; Eastern New York Regulation 2:1, supra note 9; Division of Probation Regulation 1(a)(2), supra note 9 (followed in Michigan and Pennsylvania, see note 9 supra).

By not asking for or recording information relating to the offense, PSAs attempt to minimize the possibility that incriminating admissions will be disclosed to the prosecutor and used against a defendant. This Note assumes that PSAs will not collect information about the offense. Were such information collected, greater safeguards would be necessary than those proposed in this Note.

It should be emphasized, however, that by restricting the scope of its inquiry, the PSA may limit its ability to help courts make more informed release decisions. Where a defendant is charged with a serious crime, information concerning the nature and circumstances of the offense and the weight of the evidence against the accused may have far greater influence on the bail decision than the information currently collected by PSAs. If the evidence against a defendant is strong, a judicial officer may fear that the possibility of long incarceration will induce a defendant to flee despite his community ties, or that, if released, the defendant will commit another crime. SENATE REPORT, supra note 1, at 24-25. Unless PSAs can provide an objective evaluation of these factors, they will be unable to assist the court in these difficult cases. This in turn may limit their ability to achieve reductions in pretrial detention for high-risk defendants.

18. Verification is conducted by telephone, correspondence, or visits to a defendant's residence. The verification process may generate additional information about a defendant for the PSA file, including educational or military records and details of prior contact with law enforcement agencies. Interview with John Schoenberger, Pretrial Services Officer, Southern District of New York, in New York City (Aug. 25, 1976) (notes on file with Yale Law Journal) [hereinafter cited as Schoenberger Interview]; Telephone Interview with Dan Ryan, Chicf Pretrial Services Officer, Eastern District of New York (Sept. 21, 1976) (notes on file with Yale Law Journal) [hereinafter cited as Ryan Interview].

19. In recommending conditions of release the PSA is governed by the provisions of the Bail Reform Act, 18 U.S.C. $\$ \$ 3041,3141-3143,3146-3152,3568$ (1970). In noncapital cases the Act requires the judicial officer to release a defendant on his personal recognizance or upon the execution of an unsecured appearance bond unless the officer determines "that such a release will not rcasonably assure the appearance of the person as required." Id $\$ 3146(\mathrm{a})$. If such a determination is macle,

the judicial officer shall, either in lieu of or in addition to the above methods of release, impose the first of the following conditions of release which will reasonably assure the appearance of the person for trial or, if no single condition gives that assurance, any combination of the following conditions:

(1) place the person in the custody of a designated person or organization agreeing to supervise him; 
form contains substantially less information and detail than the PSA file itself. 20

If a defendant is released under the supervision of the PSA, a schedule of contacts with the PSA is established to ensure the defendant's continued presence in the jurisdiction, to notify the defendant of required court appearances, and to monitor the defendant's compliance with any other conditions of release imposed by the court. ${ }^{21}$ Supervision of the defendant may result in the production of additional summary reports to the court, since the PSA must "inform the court of all apparent violations of pretrial release conditions or arrests of persons released to its custody or under its supervision and recommend appropriate modifications of release conditions." 22

(2) place restrictions on the travel, association, or place of abode of the person during the period of release;

(3) require the execution of an appeaxance bond in a specified amount and the deposit in the registry of the court, in cash or other security as directed, of a sum not to exceed 10 per centum of the amount of the bond, such deposit to be returned upon the performance of the conditions of release;

(4) require the execution of a bail bond with sufficient solvent sureties, or the deposit of cash in lieu thereof; or

(5) impose any other condition deemed reasonably necessary to assure appearance as required, including a condition requiring that the person return to custody after specified hours.

Id. In capital cases or after conviction, a defendant may be ordered detained if the judicial officer finds that none of the above conditions "will reasonably assure that the person will not flee or pose a danger to any person or to the community" or "if it appears that an appeal is frivolous or taken for delay." $I d$. $\$ 3148$.

Defendants are supervised by the PSA pursuant to id. $\$ 3146(a)(1)$. Typical conditions of release recommended by PSAs as part of PSA supervision include: (1) requiring a defendant to call in and speak to a pretrial services officer weekly; (2) requiring a defendant to enter a treatment program if he has a drug problem; (3) requiring a defendant to come into the PSA office on a regular basis if he has weak ties to the community; (4) requiring a defendant to seck or maintain cmployment; and (5) requiring a defendant to remain in the jurisdiction. Schoenberger Interview, supra note 18; Ryan Interview, supra note 18.

20. The PSA summary report to the judicial officer contains the defendant's name, address, telephone number, length of residence in community, social sccurity number, name and address of employer or school, length of time in job or school, and weckly earnings. The report also briefly summarizes the defendant's family ties, financial resources, health, and prior convictions and record of appearance. This summary adds few, if any, specific facts to the report. For a description of the range of information in the PSA file, see note 23 infra.

21. The process of supervising a defendant and monitoring his compliance with conditions of release is comparable to probation or parole supervision. The PSA seldom places a defendant under physical surveillance, although compliance with the condition that a defendant live at a specific address may be checked by a "home visit." PSAs maintain contact with a defendant by telephone, letter, or through regular visits by a defendant to the PSA office. Where a defendant is required to participate in a drug or alcohol program, the PSA receives reports of his compliance from the staff of the rehabilitation program. Schoenberger Interview, supra note 18; Ryan Interview, supra note 18 .

22. I8 U.S.C. $\$ 3154(5)$ (Supp. V 1975). Supplemental reports to the court may be required if a defendant or the Government seeks to modify a defendant's release conditions. See id. $\$ 3154(2)$. An updated report may also be presented to the court when a 
Thus, in the course of its relationship with a defendant, the PSA develops a file that may contain a substantial amount of information, including a record of the defendant's contacts with the PSA and of his compliance with the conditions of his release. ${ }^{23}$

\section{B. Restrictions on the Use and Disclosure of PSA Information}

In federal districts without a PSA program, information provided by a defendant in order to secure pretrial release is not confidential. A defendant is advised of his right to remain silent by an assistant United States attorney prior to the bail hearing,, ${ }^{24}$ or by the judicial officer at the outset of the hearing. ${ }^{25}$ If a defendant waives his right to remain silent and volunteers information regarding his eligibility for pretrial release, anything he says may later be used against him. ${ }^{26}$

Congress believed, however, that these procedures would deter defendants from providing the information PSAs would need to function effectively. ${ }^{2 \tau}$ Title II therefore provides that PSA information "shall be used only for the purpose of a bail determination and shall

defendant enters a plea, when a case is assigned to a particular judge, when a defendant fails to appear or is convicted, or whenever a reevaluation of cligibility for release would be appropriate. Schoenberger Interview, supra note 18; Ryan Interview, supra note 18.

23. The PSA file includes all information solicited from the defendant during the initial interview, including name, age, place of birth, citizenship, sex, race, physical description, education, marital status, dependents, residence, criminal record, detailed financial information, history of medical or psychological problems, drug or alcohol abuse, employment, and military service, and the names of persons who can verify this information. The file also includes information received from employers, educational institutions, the military, doctors, and law enforcement agencies that have been contacted by the PSA to verify information provided by the defendant. This may include information about the defendant's previous contact with law enforcement agencies (e.5., presentence investigations, reports of psychological and family history prepared by probation departments or juvenile authorities, or the details of previous offenses). Schoenberger Interview, supra note 18; Ryan Interview, supra note 18; author's inspection of representative PSA files in the Southern District of New York (Aug. 25, 1976) (notes on file with Yale Law Journal).

24. In some federal districts a defendant is interviewed prior to the bail hearing by an assistant United States attorney in order to gather information about his eligibility for bail. Telephone Interview with Guy Willetts, Chief Pretrial Services Officer, Pretrial Services Branch, Administrative Office of the United States Courts (Dec. 14, 1976) (notes on file with Yale Law Journal); Ryan Interview, supra note 18. Since a defendant may also be asked for information about the offense with which he is charged, he must be advised of his rights under Miranda v. Arizona, 384 U.S. 436 (1966). See United States v. Duvall, 597 F.2d 15, 24 (2d Cir.), cert. denied, 426 U.S. 950 (1976) (defendant's Miranda rights must be scrupulously observed in "pre-appearance interviews" by United States attorney).

Courts have held, however, that information obtained without advising a defendant of his Miranda rights need not be excluded where law enforcement officials only inquire about "pedigree" information, such as name, age, address, or marital status. See, e.g., United States ex rel. Hines v. LaVallee, 521 F.2d 1109, 1112-13 (2d Cir. 1975), cert. denied, 423 U.S. 1090 (1976) (also citing similar holdings in other circuits).

25. See Frd. R. CRIM. P. 5(c).

26. Miranda v. Arizona, 384 U.S. 436, 444 (1966).

27. SenAte Report, supra note 1 , at 52 . 
otherwise be confidential," and that it shall not be "admissible on the issue of guilt in any judicial proceeding." 28

Title II creates exceptions to this confidentiality requirement. PSAs must provide access to PSA files to "members of the agency's staff and to qualified persons for purposes of research related to the administration of criminal justice." ${ }_{9}$ PSAs are authorized to create additional exceptions to the statute's confidentiality restrictions in order to permit the release of PSA information (i) to agencies under contract to provide services to defendants under PSA supervision, (ii) to probation departments to aid in the preparation of presentence reports, (iii) to law enforcement agencies, "in certain limited cases ... for law enforcement purposes," ${ }^{30}$ and (iv) to prosecutors to be admitted on the issue of guilt for a "crime committed in the course of obtaining pretrial release." 31 The statute requires the Division of Probation and the boards of trustees to issue regulations establishing policy on the release of agency files. ${ }^{32}$

\section{The Need for Confidentiality and the Role of the} PSA in the Pretrial Release Process

\section{A. Title II and the Structure of the Pretrial Release Process}

The PSA program is part of a comprehensive reform designed "to improve the efficiency and deterrent of the federal criminal system." ${ }^{3}$ Title II of the Speedy Trial Act sets out three major goals for the

28. 18 U.S.C. $\$ 3154(1)$ (Supp. $V$ 1975). The text of the confidentiality provision is set out in full at note 8 supra.

29. 18 U.S.C. $\$ 3154(1)$ (Supp. V 1975).

30. Id. The statute itself does not specify the limited cases or purposes contemplated by this exception. Nor are they discussed explicitly in the legislative history. The Senate Report suggests that the exception might refer to the use of PSA information for the purpose of impeaching a defendant's credibility or for the purpose of prosecuting a defendant for perjury. Senate RePORT, supra note 1, at 52. The exception could also be used to permit the release of PSA information to law enforcement officials for investigation of violations of release conditions or crimes committed in the course of obtaining pretrial release. See note 83 infra.

31. 18 U.S.C. $\$ 3154(1)$ (Supp. V 1975). This Note focuses on the disclosure of PSA information to prosecutors and policc. Disclosure to other agencies or individuals for purposes referred to in the statute is not discussed, since use of PSA information for these purposes does not raise serious problems of confidentiality. For cxample, the confidentiality of presentence reports is protected by FED. R. CRIM. P. 32(c). Research information may be protected by required anonymity and nondisclosure agreements. See SENate REPorT, supra note 1, at 52. Information released to contract agencies can also be protected by nondisclosure agreements. The Division of Probation regulations, for instance, require contract agencies to complete a nondisclosure agreement. Division of Probation Regulation 4(a), supra note 9 .

32. 18 U.S.C. $\S 3154(\mathrm{I})$ (Supp. $V$ 1975).

33. SENATE REPORT, supra note 1 , at 24. 
experimental PSA program: reduction of absconding, of crime committed by defendants released before trial, and of unnecessary pretrial detention. PSAs cannot, however, realize these objectives independently. The power to release defendants on bail and to set and modify release conditions rests with the court; the power to arrest and prosecute defendants for failure to appear or for crimes committed on release rests with law enforcement agencies. PSAs can only achieve their purposes by assisting these institutions, primarily by collecting and reporting information designed to influence decisions regarding a defendant's pretrial release status.

The success of the PSAs thus depends upon their ability to provide useful information and acceptable recommendations to courts and law enforcement agencies. If PSAs unduly restrict disclosure, courts and law enforcement agencies may have insufficient information to achieve the improved pretrial release process envisioned by Title II. Moreover, these institutions may come to perceive the PSA as an advocate for the defendant, thus creating an adversary tension. Since courts and prosecutors are under no obligation to accept PSA recommendations, this tension may jeopardize the cooperation PSAs need to operate effectively.

Unfortunately, Congress failed to tailor the confidentiality restrictions of Title II to the role of the PSA program in the administration of the pretrial release process. The confidentiality provisions were adopted without careful analysis of their impact. The Senate subcommittee that developed the legislation did not scrutinize the confidentiality provisions of the statute; ${ }^{34}$ nor were they discussed during

34. The confidentiality provisions were added to the final version of the Senate bill that became the Speedy Trial Act of 1974. Compare S. 754, 93d Cong., $2 \mathrm{~d}$ Sess. (1974), reprinted in Speedy Trial Act of 1974: Hearings on S. 754, H.R. 7S73, H.R. 207, H.R. 65 , H.R. 687, H.R. 773, and H.R. 4807 Before the Subcomm. on Crime of the House Comm. on the Judiciary, 98d Cong., 2d Sess. 5-37 (1974) [hercinafter cited as 1974 Hearings], wilh S. 754, 93d Cong., 1st Sess. (1973), reprinted in Speedy Trial: Hearing on $S$. 754 before the Subcomm. on Constitutional Rights of the Senate Comm. on the Judiciary, 93d Cong., 1st Sess. 11-32 (1973). The confidentiality provisions received virtually no attention in the hearings. The only reference to the provisions is a letter from Bruce Beaudin, Director of the D.C. Bail Agency, to the minority counsel of the House Judiciary Committec. $197+$ Hearings, stupra at 766.

Mark Gitenstein, former Chief Counsel to the Subcommittee on Constitutional Rights of the Senate Judiciary Committee and principal draftsman of Title II, stated that the confidentiality provisions of the statute were adeled to the bill largely at the suggestion of Beaudin. According to Gitenstein, Beaudin believed that liberalized disclosure resulting from amendments to the D.C. Bail Agency Act, D.C. Code $\$ 23-1303$ (1973), had adversely affected the level of defendant cooperation. Telephone Interview with Mark Gitenstein (May 28, 1976) (notes on file with Yale Law Journal) [hereinafter cited as Gitenstein Interview]. The legislative history indicates that the decision to grant PSAs discretion on the issue of confidentiality was a compromise between proponents of blanket confidentiality and advocates of liberal disclosure. SenAte Report, supra note 1, at 52. 
debates on the bill. ${ }^{35}$ This lack of analysis led to basic anomalies in the statute. For example, although Title II seeks to control absconding and crime on bail, the basic "confidentiality requirement" of the statute prohibits the use of PSA information in prosecutions for such crimes. ${ }^{36}$ These anomalies have been exacerbated by the regulations adopted by the Division of Probation and the boards of trustees. The regulations, for instance, prohibit the Government from examining PSA reports and recommendations to the court at the bail hearing ${ }^{37}$ and thus limit the ability of the PSA program to improve bail decisions.

In order to develop a policy on confidentiality that is consistent with the overall structure of the release process, the need for confidentiality must be reexamined in light of the goals of Title II; the reasons for confidentiality must be carefully analyzed and balanced against the need to disclose PSA information to other institutions involved in the pretrial release process.

\section{B. The Confidentiality Principle}

Confidentiality may be supported by three considerations-the cooperation of defendants, fairness, and privacy. Of these, only the first was explicitly noted by Congress. Congress understood that the success of the PSA program would depend in part on the willingness of defendants to provide complete and accurate information. For example, if a defendant were to conceal names of friends or associates who could verify his roots in the community, the PSA might recommend a needlessly high bond, which could cause unnecessary detention of the defendant. ${ }^{38}$ Congress was particularly concerned that defendants would be reluctant to speak to PSA interviewers if the information provided could be used against them on the issue of guilt. ${ }^{30}$ The indiscriminate release of PSA information to private parties may also discourage defendants from providing complete and accurate information. Defendants have expressed concern, for instance, that the release

35. Floor discussion of the Speedy Trial Act occurred only in the House of Representatives, 120 CoNG. Rec. H12,549 (daily ed. Dec. 20, 1974); the confidentiality provisions were never mentioned.

36. Although Title II permits the limited use of PSA information "for law enforcement purposes," this exception is itself circumscribed by the statute's prohibition against use of PSA information on the issue of guilt in any judicial proceeding. 18 U.S.C. $\$ 3154$ (1) (Supp. V 1975).

37. See p. 528 and notes $52-53$ infra.

38. Similarly, a defendant's failure to disclose a drug abuse problem might deprive the PSA of an opportunity to prevent absconding or the commission of a criminal offense on release by providing for enrollment in a treatment center.

39. Senate RePort, supra note 1 , at $\mathbf{5 2}$. 
of information collected by the PSA might jeopardize their jobs or create domestic difficulties. ${ }^{40}$ Defendants have also expressed fear that the release of PSA information to law enforcement officials might subject their friends or associates to investigation or surveillance.4I Confidentiality was thus incorporated into Title II as one means of encouraging defendant participation in the program. ${ }^{42}$

Restrictions on the use of PSA information can also be justified by considerations of fairness. A defendant is ordinarily interviewed shortly after his arrest when he is under stress and unrepresented by counsel. ${ }^{43}$ His statements may not be entirely voluntary, since without his cooperation the PSA may be unable to recommend favorable release conditions. To the extent that a defendant's cooperation with the PSA is compelled by these circumstances, the use of his statements

40. For example, defendants sometimes ask that their employer or family not be called even to verify information about the defendant's roots in the community because they fear that knowledge of their arrest will have adverse consequences. Ryan Intervicw, stupra note 18; Telephone Interview with Bruce Beaudin, Director, D.C. Bail Agency (Aug. 17, 1976) (notes on file with Yale Law Journal) [hereinafter cited as Beaudin Intervicw].

41. The Director of the.D.C. Bail Agency, Bruce Beaudin, stated that defendants in some cases give false or incomplete information to the police, but give accurate information to the bail agency. Defendants have told Beaudin that this is because they want to protect their friends or family from being questioned or harassed by the police. Beaudin Interview, supra note 40 .

42. In some cases the PSA could obtain information relevant to a bail determination from sources other than a defendant. A defendant's criminal record, for example, is available. However, PSAs could not possibly obtain all the information necessary for developing release recommendations from such routine sources, nor could they complete independent investigations in the time between a defendant's arrest and the bail hearing.

43. Although defendants are told by the PSA that they have the right to talk to a lawyer before answering any questions, a defendant has no constitutional right to counsel at the PSA interview. The test for whether an accused would be entitled to counsel under the Sixth Amendment is whether the interview is a "critical stage" of the prosecution, i.e., whether the interview could substantially prejudice a defendant's rights and whether the skill of counsel could help prevent that prejudice. Coleman v. Alabama, 399 U.S. 1, 7 (1970). Gerstein v. Pugh, 420 U.S. 103 (1974), indicates that the PSA interview would not meet the "critical stage" test. In Gerstein, the Supreme Court held that a hearing to determine whether probable cause exists for a warrantless arrest, even though conducted after an information had been filed against the defendant, was not a critical stage of the prosecution "[b]ecause of its limited function and its nonadversary character." Id. at 122. Since the PSA interview is similarly limited and nonadversarial in character, it would not be a critical stage of the prosecution for which counsel must be provided.

A defendant might also assert a right to counsel to protect his Fifth Amendment rights under Miranda v. Arizona, 384 U.S. 436 (1966). But it has been held that a defendant is entitled to the protections created by Miranda only when he is questioned for investigative purposes. Miranda warnings are not required where information is solicited for purposes not related to the offense, such as booking, setting bail, or arraignment. United States ex rel. Hines v. LaVallee, 521 F.2d 1109, 1112-13 (2d Cir. 1975), cert. denied, 423 U.S. 1090 (1976). As long as the PSA does not question a defendant about his offense and solicits information only to assess eligibility for pretrial release, a defendant would not be entitled to counsel during the PSA interview under Miranda. 
as evidence against him on the issue of guilt at trial may be constitutionally prohibited.44 $\mathrm{A}$ defendant also may be more likely to offer information to a PSA representative than to a law enforcement officer, since the social service role of the PSA interviewer may encourage a defendant to be more unguarded in his statements. The PSA's declaration that it seeks information to help a defendant secure pretrial release may be viewed as creating an implied agreement that information will not be used for purposes other than setting release conditions. ${ }^{45}$ Under these circumstances it would be unfair to exploit

44. Although a defendant's participation in the PSA investigation is technically voluntary, the defendant usually must cooperate to obtain favorable pretrial releasc conditions. If the PSA has no information, it will probably be forced to recommend a high money bond. A defendant who must furnish information in order to obtain pretrial release is arguably forced to sacrifice his Fifth Amendment right to remain silent in order to exercise his Eighth Amendment right to nonexcessive bail. This analysis was adopted in State v. Williams, 343 A.2d 29, 33 (N.H. 1975), in which the court held that statements made at a bail hearing were not admissible against a defendant at his later trial. Cf. Simmons v. United States, 390 U.S. 377, 394 (1968) (tension between Fourth Amendment right to be free from unreasonable searches and seizures and Fifth Amendment right to remain silent requires that defendant's testimony to establish standing in support of a motion to suppress evidence not be admitted as evidence against him at trial on issue of guilt); Garrity v. New Jersey, 385 U.S. 493, 500 (1967) (waiver of privilege against self-incrimination induced by threat of removal from public office under state forfeiture-of-office statute held involuntary and resulting statements inadmissible in state criminal proceedings).

In its legal memorandum, the Division of Probation adopts the Simmons analysis and argues that the Constitution requires a statutory prohibition against the admission of PSA information on the issue of guilt at trial. Legal Memorandum, supra note 9, at 5-8. Although this Note supports such a restriction as a matter of policy, it should be noted that the Supreme Court recently has questioned the validity of the reasoning in Simmons. In McGautha v. California, 402 U.S. 183 (1971), vacated on other grounds, 408 U.S. 9.11 (1972), the Court found no intolerable tension between the right to remain silent and the right to be heard on punishment in a bifurcated trial where both factfinding and sentencing are performed by a jury. The Court stated that to the extent the rationale in Simmons was "based on a 'tension' between constitutional rights and the policies behind them, the validity of that reasoning must now be regarded as open to question." Id. at 212.

Moreover, although Simmons might prohibit the use of bail information to establish a defendant's guilt on the charge for which he is arrested, it would not prohibit the use of bail information for other purposes. See, e.g., Harris v. New York, 401 U.S. 222, 226 (1971) (statements excluded from Government's case-in-chief because obtained in violation of Miranda may be used to impeach); United States v. Tramunti, 500 F.2d 1334, 1342-44 (2d Cir.), cert. denied, 419 U.S. 1079 (1974) (use immunity does not cxtend to perjury); United States v. Smith, 206 F.2d 905, 907 (3d Cir. 1953) (use immunity does not extend to offenses committed after immunized testimony).

45. In State v. Winston, 300 Minn. 314, 318-319, 219 N.W.2d 617, 620 (1974), the court found that a bail agency's pledge not to ask questions regarding a defendant's offense constituted an implied agreement that the information solicited would not be used at trial. The bail agency had not in fact asked the defendant about his offense; the information introduced against the defendant by the state was his address, which had been provided in response to questions relating to his eligibility for pretrial release. Nevertheless, the court based its decision both on the implied agreement and on its concern that the admission of such evidence would jeopardize the bail program.

In Killough v. United States, 336 F.2d 929 (D.C. Cir. 1964), statements made by a de- 
a defendant's vulnerability by using this information against him at trial.

A defendant's right to privacy also militates against the disclosure of PSA information.46 PSAs routinely collect such information as a defendant's criminal record, history of drug or alcohol abuse, and names of friends and associates. Release of this information to law enforcement agencies may subject a defendant or others to surveillance or harassment, while the disclosure of this information to private parties could damage a defendant's reputation or employment opportunities. ${ }^{47}$

These three concerns-encouraging cooperation, ensuring fairness, and respecting privacy-support a general principle of confidentiality. This principle requires that the disclosure of PSA information be carefully scrutinized, and permitted only where the need for disclosure outweighs that for confidentiality.

\section{The Need for Disclosure}

The primary role of the PSA in the Title II program is to improve the release process by gathering and reporting to courts and law enforcement officials information regarding defendants and their pretrial release behavior. Confidentiality restrictions that would prevent the release of PSA information specifically designed to improve release decisions, control absconding, or reduce the incidence of crime committed on release must bear an exceptionally heavy burden of justification, since they would appear to frustrate the achievement of the overall goals of the statute. ${ }^{48}$ In fact, such restrictions are unjustifiable

fendant to a jail worker to enable the jail to classify inmates were held inadmissible against the defendant at trial because jail workers, if asked, assured defendants that their answers would not be used against them. Although Killough did not inquire about the confidentiality of his answers, the court found an "implied pledge of confidentiality as to all inmates subjected to classification questions" on the ground of "fundamental fairness" required by the due process clause. Id. at 932 .

46. According to the draftsman of Title II, the confidentiality provisions of the statute were intended to protect the privacy of defendants, although this purpose was not explicitly articulated in the legislative history. Gitenstein Interview, supra note 34.

47. PSAs are not covered by the Privacy Act of 1974, 5 U.S.C. \$552a (Supp. V 1975), because PSAs, as part of the federal court system, are not considered to be federal agencies within the meaning of the Act. See id. $\$ \$ 552 a(a), 552(e)$. Nevertheless, the Act provides a useful guide for determining the appropriate scope of disclosure of PSA information to private parties under Title II. It prohibits unauthorized disclosure of federal agency records for purposes incompatible with the purposes for which the information was collected. Id. $\$ 552 \mathrm{a}(\mathrm{b})(3)$.

48. Application of the confidentiality principle will ordinarily prevent the release of PSA information for purposes unrelated to Title II. The use of PSA information to investigate pending charges against a defendant or to investigate alleged criminal activity by his family or associates would, for instance, clearly undermine the goals implicit in 
since the disclosure of PSA information for these Title II purposes would not substantially threaten the concerns underlying the need for confidentiality. Fairness, for instance, is threatened primarily if PSA information is used to prove a defendant's guilt in the prosecution of the charge for which he has been arrested. Considerations of fairness would not be implicated if PSA information were used in prosecutions for absconding or crimes committed on release, because a defendant cannot incriminate himself in a bail interview with respect to acts that have not yet been committed. Moreover, while a defendant might infer that information provided for bail purposes would not be used with respect to pending charges, a defendant would reasonably expect such information to be used in monitoring his pretrial release behavior.

The privacy of defendants would not be violated by the release of PSA information for Title II purposes because those purposes do not require that the PSA investigate defendants or their family and friends regarding matters unrelated to a defendant's release status. Nor would Title II purposes entail the use of such information in ways calculated to harass or embarrass defendants.

Finally, it is unlikely that the release of PSA information to serve the objectives of Title II would deter defendants from cooperating with the program. Although little is known about the specific factors that encourage or inhibit defendant cooperation, it seems clear that the principal barriers to cooperation would be the use of PSA information to prosecute pending charges or to investigate a defendant or his associates in matters unrelated to the release process. Neither of these concerns, however, would be implicated in the release of PSA information for Title II purposes. The potential use of PSA information in connection with prosecutions for absconding or for crimes committed on release could only be of remote concern to most defendants in deciding whether to cooperate, since at the time of the bail interview they are presumably not contemplating jumping bail or committing a subsequent crime. And defendants are advantaged to the extent that the release of PSA information helps create a pretrial release system that is efficient and equitable.

the confidentiality principle. The use of PSA information for some other non-Title II purposes, however, might not violate the confidentiality principle, because disclosure might not be unfair, threaten a defendant's privacy, or deter cooperation. In addition, in some cases the need for disclosure for non-Title II purposes would outweigh the value of confidentiality. These considerations might dictate disclosure of information to probation officers for the preparation of presentence reports (see note 31 supra), disclosure of a defendant's whereabouts to law enforcement officials for execution of an arrest warrant, and disclosure of information that tends to cxculpate a codefendant (see, e.g., Division of Probation Regulation 9, supra note 9). 


\section{A Screen for Disclosure}

The foregoing analysis of the appropriate balance between confidentiality and disclosure in the context of the pretrial release process justifies disclosure of PSA information only with respect to that data in PSA files that must be released to facilitate achievement of Title II goals. Therefore, even when PSA information is legitimately released to other agencies in the pretrial release process, the scope of disclosure must be carefully scrutinized to assure that PSAs disclose only as much information as is demonstrably related to a particular Title II purpose. Limiting the scope of disclosure in this manner is further justified because there is some risk that PSA information, once released, could be used intentionally or inadvertently for any number of purposes. For example, if the Government obtains information necessary for its investigation of a defendant's violation of release conditions, that information may be relevant to its investigation of pending charges against a defendant; it may also create leads to evidence of a defendant's guilt. This type of secondary or derivative use of PSA information may be difficult to detect and control. ${ }^{49}$

Accordingly, in order to monitor the release of PSA information, Title II should be amended to provide a systematic screening mechanism to handle requests for PSA information. Such a procedure would ensure that the PSA discloses only the specific facts required to accommodate the particular Title II purpose for which information is requested. Since this screening function would necessarily involve the kind of delicate judgment and discretion routinely exercised by judicial officers, ${ }^{50}$ screening should be carried out by the magistrate or judge in each case. Vesting this authority in a judicial officer would maintain the credibility of the PSA program from the perspective of both the defendant and the Government. It would also enable the court to record information released to the Government and hold it responsible for any misuse or unauthorized disclosure of the information.

49. Some of the information contained in PSA files is of a kind generally accessible to law enforcement officials through other sources or independent investigation. See note 23 supra. In some cases, therefore, it would be difficult to establish that such information was in fact obtained from PSA reports or files. Cf. Kastigar v. United States, 406 U.S. 441,469 (1972) (Marshall, J., dissenting) (criticizing use immunity because of difficulty of establishing source of information used in criminal prosecution). Evidence discovered as a result of PSA information may be too far removed from its original source to be traced. The Government itself may not know whether it learned certain information from a PSA or from independent sources.

50. For example, 18 U.S.C. $\$ 3500$ (c) (1970) authorizes judges in criminal trials to inspect the statements of Government witnesses in camera to excise irrelevant material. 


\section{Guidelines for Release of PSA Information}

PSA information may be useful to law enforcement officials and may be sought by them at a number of points in the criminal process. This section evaluates the confidentiality provisions of Title II and the regulations issued by the Division of Probation and the boards of trustees in the context of these recurring occasions for exchange of PSA information. It provides guidelines for determining the proper scope of disclosure where current restrictions conflict with the purposes of Title II, and proposes a number of revisions to existing provisions. Some of these revisions may be implemented by agency regulations under the current statute; others will require statutory amendment.

\section{A. Release Hearings}

In federal districts without a PSA program, a judicial officer bases his decisions concerning a defendant's release status on information received in open court from the prosecutor, defense counsel, or the defendant himself. Under Title II, however, the officer receives bail information from another source-the PSA. Although Title II requires PSAs to submit reports to the judicial officer, ${ }^{51}$ neither the statute nor its legislative history indicates whether the prosecutor or defense counsel may have access to the PSA reports. The Division of Probation regulations provide that defense counsel, but not the prosecutor, may review PSA reports submitted to the court. ${ }^{52}$ Similar provisions or practices have been adopted by the five trustee districts. ${ }^{53}$

51. Id. \$ 3154(1) (Supp. V 1975).

52. Division of Probation Regulation 2(a), supra note 9, provides that a defendant may read the PSA report unless the judicial officer finds that disclosure would violate a pledge of confidentiality to the source of information contained in the report, or would cause harm to the defendant or other persons. Regulation 2(b) provides:

The pretrial services report respecting the matter of release determination shall not be disclosed to the attorney for the Government. The judicial officer may, in his discretion, divulge to the attorney for the Government the recommendation of the pretrial services officer regarding the defendant's release conditions.

This regulation has not been interpreted to prolibit a judicial officer from disclosing orally the contents of the PSA report to the attorney for the Government. See note 65 infra.

53. Regulations in four of the five trustee districts permit a defendant to review the PSA report. Maryland Regulation 7, supra note 9; Eastern New York Regulation 2:10, supra note 9; Division of Probation Regulation 2(a), supra note 9 (followed in Michigan and Pennsylvania, see note 9 supra). The PSA in Missouri currently does not disclose its report to the defendant. Telephone Interview with Lewis Frazier, Chief Pretrial Services Officer, Westexn District of Missouri (Oct. 19, 1976) (notes on file with Yale Law Journal) [hereinafter cited as Frazier Interview]. Such disclosure would be permitted, however, under its proposed regulations. Proposed Missouri Regulation 8, supra note 9. None of the districts permits the attorney for the Government to inspect the PSA 
This is an inappropriate restriction on disclosure. ${ }^{5+}$ Well-informed and careful release decisions are necessary to achieve the goals of Title II, and the quality of these decisions will be improved by disclosing the PSA report to the prosecutor. Traditionally, the prosecutor has played a dominant role in bail hearings as an advocate for the Government's interest in ensuring a defendant's appearance at trial. In order to represent that position intelligently, the prosecutor must know all the facts before the court. Unless he knows the contents of the PSA report, he cannot contest or supplement its factual information or challenge the reliability of its conclusions. ${ }^{55}$ For this reason the prosecutor has traditionally had access to reports to the court in jurisdictions served by programs like Title II.56 Moreover, by withholding information that is ordinarily available, ${ }^{57}$ these restrictions

report. The PSAs in Michigan and Pennsylvania have adopted Division of Probation Regulation 2(b), which explicitly prohibits disclosure of the PSA report to the Government. See note 9 supra. The proposed Missouri regulations provide that information contained in a pretrial services officer's report "shall not be disclosed to the United States except upon order of court." Proposed Missouri Regulation 9, supra note 9. Regulations in the other two districts are silent, but in practice such disclosure is not permitted. Telephone Interview with Morris Street, Chief Pretrial Services Officer, District of Maryland (Oct. 19, 1976) (notes on file with Yale Law Journal) [hereinafter cited as Street Interview]; Ryan Interview, supra note 18.

54. Mark Gitenstein, the draftsman of Title II, stated that he did not understand the confidentiality provisions to apply to information included in PSA reports to a court, and expressed some surprise that it was so construed by the Division of Probation. According to Gitenstein, the provision was intended to maintain the confidentiality of "cxtraneous" information irrelesant to the bail determination, such as incriminating admissions. Gitenstein Interview, supra note 34 .

55. Similar concerns for accuracy led to the disclosure of presentence reports to defendants. Fed. R. Crim. P. 32(c)(3)(A). See Notes of Advisory Committee on Rules, 1974 Amendment, Fed. R. Crim. P. 32(c)(3)(A), 18 U.S.C. app., at 1327 (Supp. V 1975). Any material in the presentence report disclosed to a defendant or his counsel must also be disclosed to the Government. FED. R. Crim. P. 32(c)(3)(C). Relying explicitly on the presentence report experience and rationale, one magistrate routinely discloses PSA reports to counsel for the defense and the Government. Telephone Interview with Sol Schreiber, United States magistrate, Southern District of New York (Nov. 5, 1976) (notes on file with Yale Law Journal) [hereinafter cited as Schreiber Intervicw]. Reports of similar practices in other districts are described at note 65 infra.

56. Reports of the D.C. Bail Agency must be disclosed to the Government under D.C. ConE $\S 23-1303$ (a) (1973). Copies of reports prepared for the judge by bail agencies operated by the Vera Institute of Justice in New York Gity are given to both the assistant district attorney and defense counsel. Telephone Interview with Deborah Fitzgibbons, Deputy Director, Vera Pretrial Services Agency (Dec. 6, 1976) (notes on file with Yale Law Journal) [hereinafter cited as Fitzgibbons Interview]. In some jurisdictions bail agencies are actually operated by law enforcement agencies. See BaIL and Summons: 1965, at 8 (Proceedings of the Institute on the Operation of Pretrial Release Projects and Justice Conference on Bail and Remands in Custody 1965). Bail information provided by defendants is therefore known to law enforcement officials and may be passed on to prosecutors.

57. See p. 519 supra. One PSA has sought to continue the prior practice. Although governed by the Division of Probation, it has refused to follow Division of Probation regulations; reports are routinely given to the United States attorney because "[d]isclosure of this kind has been the general rule in this Court historically [and] has 
may alienate the prosecutor, ${ }^{58}$ thus jeopardizing the cooperation needed to effect improvements and reforms in the release process.

In opposing the release of the PSA report to the prosecutor, the Division of Probation cites the risk that PSA information will be used to investigate or prosecute the offense for which a defendant was arrested.59 Although the PSA does not ask a defendant about the circumstances of his offense and does not record unsolicited admissions, ${ }^{60}$ the Division of Probation argues that even routine background information about a defendant might become incriminating or might provide leads for further investigation of his offense. ${ }^{61}$ PSA information or facts derived from it might, therefore, actually be used to prove a defendant's guilt on pending charges-a use of PSA information forbidden by Title II. The Division of Probation contends that the only way to control such use is to withhold the PSA report from the Government. ${ }^{\circ 2}$

The release of the PSA report to the Government would not, however, entail access to the entire PSA file. Reports to the court usually contain general characterizations or summaries of a defendant's background-not specific information such as names or addresses. Most of the detailed information in PSA files is not reported to the court at all. ${ }^{63}$ Thus, the PSA report does not ordinarily contain information sufficiently specific to provide evidence in the prosecution of pending charges or to offer substantial investigative leads. Indeed, the abuse feared by the Division of Probation has not in fact occurred where bail agency reports containing the same type of information are routinely disclosed to the Government. ${ }^{64}$

speeded up the hearings and resulted in quick agreement between the defendants and the prosecution." Memorandum from Robert Mr. Latta, Chief Probation Officer, Los Angeles, to Guy Willetts, Chief, Pretrial Services Branch, Administrative Office of the United States Courts (Apr. 16, 1976) (on file with Yale Law Journal).

58. Dan Ryan, Chief Pretrial Services Officer in the Eastern District of New York, reported that the PSA was initially viewed as an adversary by some assistant United States attorneys in his district, largely because they feared that PSAs would interfere with their control over the early stages of a defendant's custody. According to Ryan, this tension was exacerbated by the regulations adopted in that district prohibiting disclosure of the PSA report to the attorney for the Government. Ryan Interview, supra note 18.

59. Legal Memorandum, supra note 9 , at 28.

60. See pp. 516-17 \& note 17 supra.

61. Telephone Interview with Judd Kutcher, Assistant General Counsel, Administrative Office of the United States Courts and coauthor of the Division of Probation regulations (May 28, 1976) (notes on file with Yale Law Joumal) [hereinafter cited as Kutcher Interview]. See State v. Winston, 300 Minn. 314, 219 N.W.2d 617 (1974). But see note 83 infra (Division of Probation regulation permitting release of defendant's whereabouts for investigative purposes).

62. Kutcher Interview, supra note 61 .

63. Compare note 20 supra with note 23 supra.

64. The Director of the D.C. Bail Agency stated that his agency has never detected abuse of this kind, nor has the Government been challenged by a defense attorney 
Moreover, the Division of Probation regulations do not prohibit the judicial officer from disclosing the contents of the report to the prosecutor, ${ }^{65}$ and Title II itself clearly contemplates open bail hearings. The statute refers, for instance, to PSA information "divulged during the course of any hearing." knowledges that much of the information contained in the PSA report may be revealed orally at the bail hearing. ${ }^{.7}$ Under these circumstances, the confidentiality of the report cannot realistically be guaranteed.

Thus, all PSA reports available to the court should be disclosed in advance to all parties. Because disclosure of the PSA report would not involve access to PSA files, screening by the court is not necessary. Disclosure may be accomplished under the current statute by revision of the PSA regulations. But to ensure uniform implementation, Title II should be amended to require such disclosure.

\section{B. Prosecution for Perjury or False Statement}

Title II provides that PSA information shall not be admissible "on the issue of guilt in any judicial proceeding." 68 The statute, however, does permit the Division of Probation and the boards of trustees to make an exception to this prohibition and provide in their regulations for the use of PSA information "on the issue of guilt for a crime committed in the course of obtaining pretrial release." 69 Neither the statute nor the legislative history indicates the scope of this exception. The phrase "in the course of obtaining pretrial release" suggests a crime occurring contemporaneously with the bail interview or bail hearing, and thus probably refers to perjury. ${ }^{70}$ Accordingly, the Divi-

regarding the source of its information. Beaudin Interview, supra note 40 . Vera officials also were unaware of any instances in which information contained in a pretrial services report had been used by law enforcement officials to investigate or to prove pending charges against a defendant. Fitzgibbons Interview, supra note 56.

65. Although Division of Probation regulations prohibit the judicial officer from showing the PSA report to the attorney for the Government, see note 52 supra, the Division of Probation interprets its regulations to permit oral disclosure of the contents of the report, Kutcher Interview, supra note 61. Nor do any of the trustee districts prohibit the judicial officer from disclosing the contents of the PSA report to the Government. See note $\mathbf{5 3}$ supra. In fact, some magistrates in both trustee districts and those governed by the Division of Probation either show the PSA report to the prosecutor or state orally the facts contained in the PSA report that are relied upon in setting release conditions. Other magistrates do not disclose the PSA report or its contents to the Government. Goussy Interview, supra note 9; Frazicr Interview, supra note 53; Williams Interview, supra note 9; Schreiber Interview, supra note 55; Street Interview, supra note $\mathbf{5 3}$.

66. 18 U.S.C. $\$ 3154(1)$ (Supp. V 1975).

67. Kutcher Interview, supra note 61 .

68. 18 U.S.C. § 3154(1) (Supp. V 1975).

69. Id.

70. The legislative history suggests that Congress contemplated the use of PSA information in prosecutions for perjury. See SENATE ReporT, supra note 1, at 52. Defendants could be prosecuted for perjury for statements made under oath to the court. 
sion of Probation regulations provide that PSA information "shall be available to law enforcement agencies and admissible as evidence on the issue of a defendant's guilt in a prosecution for perjury or false statement allegedly committed in the course of obtaining pretrial release."'r1

Defendants may make false statements or commit perjury at all stages of the release process. For example, defendants may make false statements to the PSA or the court concerning their compliance with release conditions or their failure to appear for a scheduled court appearance. The statute, however, may be read to limit the use of PSA information to crimes committed while "obtaining" pretrial release, i.e., crimes committed at the initial bail interview or bail hearing. The

Since statements made to PSA interviewers are not under oath, defendants who give false information to the PSA cannot be prosecuted for perjury. See 1S U.S.C. $\$ 1621$ (1970). Defendants can, however, be prosecuted under id. $\$ 1001$ for the knowing and willful falsification or concealment of a material fact within the jurisdiction of any department or agency of the United States. Under the reasoning of United States v. Bramblett, 348 U.S. 503, 509 (1955), a PSA is a "department or agency" of the United States within the meaning of this statute.

The exception for crimes committed in the course of release might also be applied to the bribing or threatening of a pretrial services officer. Arthur Goussy, Chief Pretrial Services Officer in the Eastern District of Michigan, stated that one of his employees was threatened by a defendant in the course of a bail interview. The interviewer put the facts of the incident on record at the bail hearing, and, Goussy asserted, would have been able to testify at trial because of the statutory exception for crimes committed in the course of obtaining release. Goussy did not know, however, whether the defendant in this particular case was actually charged with threatening. Goussy Interview, supra note 9. Although permitted by the statute, the use of PSA information in the prosecution of such a crime would appear to conflict with the Division of Probation regulations, adopted by the Eastern District of Michigan (see note 9 supra), which allow the use of PSA information only in prosecutions for the crimes of perjury or false statement committed in the course of obtaining release. Division of Probation Regulation 7, supra note 9.

Similarly, neither the Division of Probation regulations nor the regulations developed by the boards of trustees in Pennsylvania and Missouri contain a general exception to the confidentiality requirement for crimes committed in the course of obtaining release; they limit the use of PSA information to prosecutions for perjury or false statement committed in the course of obtaining release. Division of Probation Regulation 7, supra note 9 (also followed in Pennsylvania, see note 9 supra); Proposed Missouri Regulation 7, supra note 9. The District of Maryland has not adopted a regulation concerning the use of PSA information in the prosecution of crimes committed in the course of obtaining pretrial release. These regulations should be amended to permit the use of PSA information in the prosecution of any crime committed in the course of obtaining pretrial release in order to ensure the integrity of the PSA program. Such a regulation has been adopted by the board of trustees in the Eastern District of New York. Eastern New York Regulation 2:9, supra note 9 .

71. Division of Probation Regulation 7, supra note 9 (cmphasis in original). See Legal Memorandum, supra note 9, at 26-27. Four of the five trustee districts have similar provisions. Proposed Missouri Regulation 7, supra note 9; Eastern New York Regulation 2:9, supra note 9; Division of Probation Regulation 7, supra (followed in Michigan and Pennsylvania, see note 9 supra). The board of trustees in Maryland has not adopted a regulation concerning perjury. 
Division of Probation regulations perpetuate this confusion by tracking the language of the statute.

Title II should provide for the use of PSA information in prosecutions for false statements made or perjury committed at any stage of the release process. The PSA program was designed to improve the quality of the bail determination by increasing the amount and reliability of information available to the court. Penalizing the provision of false information to the PSA or the court will promote truthfulness. Indeed, if defendants were immune from sanctions for abusing the PSA process, the confidence of courts and prosecutors in PSA release recommendations would ultimately be undermined. This policy could be implemented by interpreting "obtaining pretrial release" to include any act designed to secure or maintain favorable release conditions. To assure adoption of this policy, Title II should be amended to provide unambiguously for the use of PSA information in prosecutions for giving false information to PSAs or courts at any stage of the release process.

The appropriate scope of disclosure for these purposes could easily be determined by a judicial screening procedure. Only the content of the false statement and any information obtained by the PSA that establishes the true facts need be released. Because the scope of information necessary for a false statement prosecution is narrow, the possibility of indiscriminate derivative use should be slight.

\section{Prosecution for Failure to Appear}

A major goal of Title II is the prevention and control of absconding, yet the statutory prohibition on the use of PSA information "on the issue of guilt in any judicial proceeding" apparently prohibits the use of PSA information in a prosecution for failure to appear. ${ }^{72}$ The Division of Probation regulations, which track the language of this prohibition, have been interpreted to this effect. ${ }^{73}$

72. The term "judicial proceeding" is not defined in the statute or the legislative history. The draftsman of Title II has stated, however, that the statute was not intended to prohibit the use of PSA information in a prosecution for failure to appear, although he concedes that the statutory language has failed to make that intent explicit. Gitenstein Interview, supra note 34 .

73. The Division of Probation regulations, and those of the trustee districts, follow the language of the statute. Division of Probation Regulation 1(b), supra note 9 (also followed in Michigan and Pennsylvania, see note 9 supra); Maryland Regulation $\mathrm{I}(\mathrm{b})$, supra note 9; Proposed Missouri Regulation 1(b), supra note 9; Eastern New York Regulation 2:2, supra note 9. The Division of Probation interprets the statutory prohibition to prevent the use of PSA information in any criminal prosecution, including a prosecution for failure to appear. Legal Mcmorandum, supra note 9, at 26; Kutcher Interview, supra note 61 . 
Under federal law, the willful failure to appear as required before any court or judicial officer is a criminal offense. ${ }^{74}$ This criminal sanction serves as a deterrent to bail jumping. However, the confidentiality requirement of Title II, and the regulations promulgated pursuant to it, may cripple prosecutions for failure to appear. PSAs often possess important evidence on the issue of willfulness: since they notify defendants of their obligations to appear in court, often only a PSA will know whether a defendant was aware of his court date. ${ }^{\text {To }}$ The statutory and regulatory restrictions on the use of PSA information may thus frustrate the efficient administration of the pretrial release process by effectively preventing the imposition of sanctions for absconding. ${ }^{76}$

There is only limited information in a PSA file relevant to a prosecution for failure to appear. A judicial officer need release only information indicating whether a defendant knew about his scheduled court appearance, or information confirming or refuting a defendant's excuse for nonappearance. There is virtually no possibility that this information could be used for purposes unrelated to Title II. Title II should therefore be amended to provide for the use of PSA information in all criminal prosecutions for failure to appear.

\section{The Pending Charge and Impeachment of the Defendant}

Although Title II prohibits the use of PSA information against a defendant on the issue of his guilt, it does not prevent the use of PSA information to impeach a defendant's credibility by demonstrating

74. 18 U.S.C. $\$ 3150$ (1970). Since some magistrates include a requirement that a defendant appear for all scheduled court appearances among the conditions of release set at the initial bail hearing, failure to appear may often constitute a violation of release conditions. Although the court may hold in contempt a defendant who fails to comply with the conditions of his release, see 18 U.S.C. $\$ 3151$ (1970), violation of conditions is usually not a criminal offense, and the legislative history states that PSA information may be used in "hearings where there is an apparent violation of release conditions." SENATE REPORT, supra note 1 , at 52.

75. Although the statute does not require PSAs to perform this notification function, all 10 PSAs do notify defendants to some extent. The process is more systematic in some districts than in others. Telephone Interview with Roger LeBoeuf, Pretrial Services Specialist, Administrative Office of the United States Courts (Sept. 22, 1976) (notes on file with Yale Law Journal).

76. The use of information gathered by the D.C. Bail Agency was originally permitted only in bail hearings. In 1970 Congress specifically authorized the use of agency information in prosecutions for absconding because the earlier confidentiality provisions had prevented Bail Agency members from informing the court whether a defendant had been notified when to appear in court. D.C. CodE $\$ 23-1303$ (d) (1973); H.R. REP. No. 91907, 91st Cong., 2d Sess. $116(1970)$. Since the D.C. experience was the model for Title II, the 1970 legislation suggests that had the confidentiality provisions of Title II received sufficient scrutiny, they probably would have provided clearly for the use of PSA information in a prosecution for failure to appear. 
inconsistencies between testimony at trial and information in PSA reports or files. ${ }^{77}$ Indeed, the legislative history indicates that the disclosure of PSA information to impeach a defendant's credibility was one of the optional law enforcement purposes specifically contemplated by the drafters of the confidentiality provisions. ${ }^{78}$

The primary purpose of impeaching a defendant's credibility is to secure conviction. The use of PSA information for this purpose has the same effect as using PSA information on the issue of guilt-a use inconsistent with the bases of the confidentiality principle. ${ }^{79}$ The Division of Probation's current regulations and those adopted by four of the five boards of trustees prohibit the use of PSA information to impeach a defendant. ${ }^{80}$ These regulations, however, could be modified to permit such use. In order to ensure that current PSA policy remains in effect and is implemented uniformly in each PSA district, Title II should be amended to prohibit impeachment use.

\section{E. Prosecution for Crime on Release}

The control of crime on release is one of the major goals of Title II. Congress established the PSA program in part to test whether increased supervision of persons released prior to trial could reduce the incidence of crime on bail. However, the statutory prohibition against the use of PSA information on the issue of guilt in any judicial proceeding prevents PSAs from providing information in prosecutions for crimes committed on release. ${ }^{\$ 1}$

Once again, this restriction on the use of PSA information conflicts

77. 18 U.S.C. $\$ 3154(1)$ (Supp. V 1975).

78. SENATE REPORT, supra note 1 , at 52.

79. Sce pp. 522-25 supra. It might be asserted that the use of PSA information to impeach a defendant furthers the goals of Title II by penalizing defendants for making false statements to the PSA. But this purpose would be accomplished only in those cases in which a defendant goes to trial, takes the stand, and testifies truthfully. Prosecution for false statement is therefore a more direct and effective method of promoting truthful statements. Morcover, impeachment use raises substantial problems concerning the scope of disclosure, for if impeachment is truly to serve as a check on the truthfulness of a defendant's statements to the PSA, the prosecutor should be aware of the contents of the entire PSA file. Such unrestricted governmental access would effectively destroy the confidentiality of the PSA file and create the risk of extensive derivative use of PSA information.

80. Division of Probation Regulation 8, supra note 9 (also followed in Michigan and Pennsylvania, see note 9 supra); Maryland Regulation 8, supra note 9; Eastern New York Regulation 11, supra note 9. Impeachment use is not mentioned in the proposed regulations of the Missouri PSA.

81. Division of Probation Regulation 1(b), supra note 9, which prohibits the use of PSA information on the issue of guilt in any judicial proceeding, has been interpreted to prohibit use of PSA information in a prosecution for crimes committed on release. Legal Memorandum, supra note 9, at 26; Kutcher Interview, supra note 61. The trustee district regulations also prohibit the use of PSA information on the issue of guilt in any judicial proceeding. See note 73 supra. 
with the larger goals of the PSA program. Depending on the intensity of pretrial supervision, PSA officers may actually observe or acquire evidence relating to crimes committed on release. ${ }^{82}$ By refusing to release such information, the PSA not only prevents law enforcement agencies from prosecuting such crimes, but also may antagonize other institutions in the criminal justice system. If courts and prosecutors come to regard the PSA as an advocate for the defendant, the PSA may lose the cooperation necessary to function properly. Courts may be reluctant to release high-risk defendants into PSA custody if confidentiality restrictions prevent or seriously disadvantage prosecution of defendants for crimes committed on release.

Title II should therefore be amended to permit the use of PSA information in prosecutions for crimes committed on release. The scope of disclosure for this purpose, however, could be very difficult to limit; a prosecutor may argue that he needs-access to the entire PSA file in order to develop a case against a defendant. Therefore, the judicial officer should carefully supervise the disclosure of PSA information to prevent speculative or exploratory requests. Disclosure should be limited to those situations in which specific and discrete facts useful to the prosecutor can be identified. For example, the judicial officer could disclose eyewitness accounts of a crime on release or specific facts relating to the crime, such as the defendant's whereabouts on a particular occasion, his knowledge of a specified skill, or acquaintance with a certain individual. ${ }^{83}$

82. The Director of the D.C. Bail Agency reported that agency staff had occasionally witnessed minor thefts by defendants on the premises of the bail agency. Beaudin Interview, supra note 40 . Complaining witnesses had occasionally notified the bail agency that defendants under bail agency supervision had assaulted or bothered them, and a defendant's family or friends had often provided information that a defendant might commit or had committed the crime of bail jumping. Id.

83. PSA information may also be useful to law enforcement officials in investigating allegations of violations of release conditions, perjury, failure to appear, or crimes committed on release. Current statutory provisions that prohibit the use of PSA information on the issue of guilt-for example, in prosecutions for failure to appear or for crimes committed on release-would, however, also prohibit investigative use, since investigations are designed to develop proof of guilt. On the other hand, the statutory prohibition against the use of PSA information on the issue of guilt would not bar the use of PSA information to investigate perjury or violations of release conditions, since the use of PSA information in violation hearings and perjury prosecutions is permitted. The disclosure of PSA information for investigative purposes in these cases is arguably further justified under the optional exception to the confidentiality requirement permitting the release of agency files "in certain limited cases to law enforcement agencies for law enforcement purposes.” 18 U.S.C. $\$ 3154(1)$ (Supp. $V$ 1975).

Most of the regulations provide that PSA information may be released to law enforcement agencies to investigate violations of conditions, failure to appear, and crimes committed on release, but limit the scope of disclosure to the whereabouts of a defendant. Division of Probation Regulation 6, supra note 9 (also followed in Michigan and Pennsylvania, see note 9 supra); Maryland Regulation 6, supra note 9 (failure to 
Prompt adoption of this and other reforms proposed in this Note, either by statutory amendment or agency regulation, will provide a more accurate test of the ability of PSAs to improve the federal pretrial release process, thereby fulfilling Congress's purpose in instituting the Title II experiment.

appear only); Eastern New York Regulation 2:8, supra note 9 (failure to appear and violation of conditions); Proposed Missouri Regulation 6, supra note 9. The limitation to information concerning a defendant's whereabouts is not explained in the regulations or in the Division of Probation legal memorandum, supra note 9. The Division of Probation finds authority for its provisions on investigative use in the "limited law enforcement" exception to the confidentiality requirement. Legal Memorandum, supra note 9, at 25. Arguably, a defendant's whereabouts could never be used to prove his guilt, and thus disclosure of such information would not conflict with the statutory prohibition. But see State v. Winston, 300 Minn. 314, 219 N.W.2d 617 (1974). But where PSA information is admissible on the issue of guilt in a particular proceeding, there is no reason to limit the scope of disclosure for investigative purposes to information concerning a defendant's whereabouts.

Title II should be amended to permit the release of any information that is demonstrably related to the investigation of a defendant's pretrial release behavior. This would include not only a defendant's whereabouts, but also information tending to refute or corroborate an alibi, or establishing a defendant's relationship to a particular individual or event. In the interim the Division of Probation and the boards of trustees should amend their regulations to provide for such use where the statute currently permits, e.g., in connection with violations of release conditions or with crimes committed in the course of obtaining release. 